\title{
MOTIF DAN KONTRIBUSI PENDAPATAN PEREMPUAN PEDAGANG IKAN ASIN TERHADAP PENINGKATAN EKONOMI RUMAH TANGGA NELAYAN
}

\author{
(Motive And Contribution Of Female Assembly Women Traders On The Improvement Of \\ Fisherman's Household Economics)
}

\author{
Muhammad Rizki Aulia ${ }^{1}$, Mustafa Usman ${ }^{1,}$ Elly Susanti ${ }^{1 *}$ \\ ${ }^{1}$ Program Studi Agribisnis, Fakultas Pertanian, Universitas Syiah Kuala
}

\begin{abstract}
Abstrak. Masyarakat yang berada di kawasan pesisir menghadapi berbagai permasalahan yang menyebabkan kemiskinan. Berbagai strategi dilakukan oleh keluarga nelayan seperti pemanfaatan tenaga kerja yang berasal dari keluarga, yakni istri dan anak-anaknya. pemanfaatan atau keterlibatan perempuan sebagai pekerja di sektor publik disamping peran utamanya sebagai ibu rumah tangga, yaitu merupakan salah satu bentuk strategi yang di upayakan di dalam rumah tangga nelayan di daerah Teluk Lhok Seudu untuk berkontribusi terhadap pendapatan ekonomi keluarganya. Penelitian ini dilakukan dengan tujuan untuk mengetahui motif perempuan rumah tangga nelayan bekerja sebagai pedagang ikan asin dan untuk mengetahui tingkat kontribusi pendapatan perempuan yang bekerja sebagai pedagang ikan asin terhadap peningkatan ekonomi rumah tangga nelayan. Metode penelitian yang digunakan adalah metode penelitian survey dengan populasi dalam penelitian ini berjumlah 23 orang yang keseluruhan anggotanya bekerja pada kelompok pengelola ikan asin Mawar Putih. Metode analisis yang digunakan pada penelitian ini adalah metode deskriptif kualitatif dan kuantitatif. Motif perempuan pedagang ikan asin bekerja di desa Lhok Seudu Kecamatan Leupung Kabupaten Aceh Besar pada umumnya untuk menambah penghasilan keluarga. Tingkat kontribusi yang diberikan pedagang perempuan responden terhadap peningkatan ekonomi rumah tangganya berkategori sedang dengan acuan jika pendapatan dari perempuan nelayan pedagang ikan asin 35\% - 75\% dari total pendapatan rumah tangga.
\end{abstract}

Kata kunci: Motif, Kontribusi pendapatan, Peningkatan ekonomi

\begin{abstract}
Communities located in the coastal areas face various problems that cause poverty. Various strategies are carried out by families of fishermen such as the utilization of labor that comes from the family, namely his wife and children. utilization or involvement of women as workers in the public sector in addition to their primary role as housewives, which is one form of strategy that is attempted in fishermen's households in Lhok Seudu Bay area to contribute to the income of their family's economy. This research was conducted with the aim to know the motives of household women fishermen working as salted fish traders and to know the level of income contribution of women who work as salted fish traders to the economic improvement of fishermen households. The research method used is survey research method with the population in this study amounted to 23 people whose entire members work on the saltwater fish management group Mawar Putih. The method of analysis used in this research is descriptive qualitative and quantitative methods. The motive of salted fish traders working in Lhok Seudu village, Leupung district, Aceh Besar regency in general to supplement family income. The contribution rate given by the female traders of respondents to the household economic improvement is categorized by reference if the income of the salted fish traders women 35\% - 75\% of the total household income.
\end{abstract}

Keywords: Motives, Revenue Contribution, Increased economy

\section{PENDAHULUAN}

Masyarakat yang berada di kawasan pesisir menghadapi berbagai permasalahan yang menyebabkan kemiskinan. Pada umumnya mereka menggantungkan hidupnya dari pemanfaatan sumberdaya laut dan pantai yang membutuhkan investasi besar dan sangat bergantung musim. Sebagian besar dari mereka bekerja sebagai nelayan kecil, buruh nelayan, pengolah ikan skala kecil dan pedagang kecil karena memiliki kemampuan investasi terbatas.

Berbagai strategi dilakukan oleh keluarga nelayan seperti pemanfaatan tenaga kerja yang berasal dari keluarga, yakni istri dan anak-anaknya. Berbagai studi menyebutkan bahwa keterlibatan istri nelayan memiliki kontribusi yang besar terhadap ekonomi rumah tangga nelayan (Handoko, Marwah, dan Ardhanariswari, 2012; Harahap, Fauzia, dan 
Emalisa, 2013). Mereka menjalankan peran ganda dalam rumah tangga, yakni bertanggungjawab terhadap berbagai urusan domestik di rumah dan juga terlibat dalam urusan pekerjaan publik sebagai pekerja tambahan untuk mencukupi kebutuhan ekonomi rumah tangga.

Salah satu wilayah pesisir di Aceh yang melibatkan perempuan sebagai penyokong ekonomi rumah tangga nelayan yaitu terdapat di daerah Teluk Lhok Seudu Desa Layeun Kecamatan Leupung Kabupaten Aceh Besar. Lhok Seudu terletak di desa Layeun. Masyarakat di daerah pesisir (Lhok Seudu) tersebut umumnya bekerja sebagai nelayan dan pengolah hasil perikanan. Profesi nelayan di Teluk Lhok Seudu pada umumnya dikerjakan oleh laki-laki, sedangkan yang mengolah hasil perikanan dan juga memperdagangkan hasil olahan ikan dilakukan oleh perempuan (istri nelayan). Jadi pemanfaatan atau keterlibatan perempuan sebagai pekerja di sektor publik disamping peran utamanya sebagai ibu rumah tangga, yaitu merupakan salah satu bentuk strategi yang di upayakan di dalam rumah tangga nelayan di daerah Teluk Lhok Seudu untuk berkontribusi terhadap pendapatan ekonomi keluarganya.

\section{METODE PENELITIAN}

Penelitian ini dilakukan di Teluk Lhok Seudu Desa Layeun Kecamatan Leupung Kabupaten Aceh Besar. Penentuan lokasi ini ditentukan dengan sengaja (Purposive) yaitu berdasarkan pertimbangan-pertimbangan tertentu disesuaikan dengan tujuan penelitian. Populasi dalam penelitian ini berjumlah 23 orang yang keseluruhan anggotanya bekerja pada kelompok pengelola ikan asin Mawar Putih Lhok Seudu di Desa Layeun Kecamatan Leupung Kabupaten Aceh Besar. Pengambilan sampel dilakukan dengan sengaja (purposive sampling). Sampel di dalam penelitian ini diambil 18 orang. Penelitian ini terdiri dari dua kategori yaitu, kategori perempuan yang masih memilik suami yang berjumlah 15 orang dan kategori perempuan berstatus janda yang berjumlah 3 orang. Jenis data yang yang dikumpulkan dalam penelitian ini adalah data primer dan data sekunder. Data primer didapat dari dua macam teknik pengumpulan data, yaitu wawancara dan kuesioner. Metode analisis yang digunakan pada penelitian ini adalah metode deskriptif kualitatif dan kuantitatif. Analisis data kualitatif adalah bersifat induktif, yaitu suatu analisis berdasarkan data yang diperoleh selanjutnya dikembangkan pola hubungan tertentu atau menjadi hipotesis (Sugiyono, 2010) Berdasarkan hipotesis yang telah dirumuskan maka selanjutnya mencari data lagi secara terus - menerus agar dapat digeneralisasikan apakah hipotesis diterima atau ditolak berdasarkan data valid yang telah terkumpul. Ketika hipotesis diterima berdasarkan data yang terkumpul maka hipotesis dapat berkembang menjadi teori. Statistik deskriptif digunakan dalam mengelola dan mendeskripsikan data dalam bentuk tampilan data yang lebih bermakna dan mudah dipahami oleh orang lain. Penelitian ini dilakukan bertujuan untuk mengetahui pengaruh kontribusi perempuan nelayan pedagang ikan asin terhadap pendapatan rumah tangga (Hadeli, 2006).

Pembagian motif di dalam penelitian ini akan dibahas dengan tiga motif, menurut Sajogyo (1985) mengemukakan bahwa motif perempuan bekerja di sektor informal terbagi menjadi tiga motif yaitu :

1. Motif untuk membantu menambah penghasilan ekonomi keluarganya.

2. Motif sebagai pencari nafkah utama di dalam keluarga.

3. Motif sebagai pengisi waktu luang.

Untuk mengetahui pendapatan yang didapat perempuan nelayan pedagang ikan asin terhadap rumah tangga dapat dihitung dengan rumus pendapatan, yaitu : 
$\pi=\mathrm{TR}-\mathrm{TC}$

.(Sukirno, 2002)

Dimana :

$\pi=$ Pendapatan perempuan nelayan pedagang ikan asin (Rp/Bulan)

$\mathrm{TR}=$ Total Penerimaan (Rp/Bulan)

$\mathrm{TC}=$ Total Biaya $(\mathrm{Rp} /$ Bulan $)$

Kontribusi $=\frac{\lambda 1}{\lambda \text { total }} \times 100 \%$ (Soekartiwi, 1993)

Dimana :

$\lambda_{1}=$ Pendapatan perempuan nelayan sebagai pedagang ikan asin (Rp/Bulan).

$\lambda_{\text {total }}=$ Total pendapatan rumah tangga nelayan dari pendapatan suami sebagai nelayan dan istri sebagai pedagang ikan asin asin (Rp/Bulan).

Menurut Fachruddin (2011), untuk mengetahui besaran kontribusi pendapatan dapat diukur dan diambil keputusan dengan kriteria, sebagai berikut :

1. Apabila pendapatan dari perempuan nelayan pedagang ikan asin $>75 \%$ dari total pendapatan rumah tangga maka di kategorikan tinggi, jadi pendapatan tersebut merupakan pendapatan utama rumah tangga perempuan nelayan pedagang ikan asin.

2. Apabila pendapatan dari perempuan nelayan pedagang ikan asin 35\% - 75\% dari total pendapatan rumah tangga maka di kategorikan sedang, jadi pendapatan tersebut bukan merupakan pendapatan utama rumah tangga perempuan nelayan pedagang ikan asin.

3. Apabila pendapatan dari perempuan nelayan pedagang ikan asin $<35 \%$ dari total pendapatan rumah tangga maka di kategorikan rendah, jadi pendapatan tersebut bukan merupakan pendapatan utama rumah tangga perempuan nelayan pedagang ikan asin.

\section{HASIL PENELITIAN DAN PEMBAHASAN}

\section{Motif Pedagang Perempuan Bekerja Terhadap Peningkatan Ekonomi Rumah Tangga}

Motif utama perempuan di pedesaan untuk bekerja pada umumnya disebabkan karena tuntutan ekonomi keluarga atau menambah pendapatan keluarga. Mereka menganggap kebutuhan hidup keluarga semakin bertambah dan apabila hanya mengandalkan gaji dari suami tidak cukup untuk memenuhi kebutuhan hidup keluarga. Untuk melihat persentase motif perempuan bekerja terhadap peningkatan ekonomi rumah tangga dapat dilihat pada tabel data berikut ini.

Persentase Motif Pedagang Perempuan Responden Bekerja pada Usaha dagang Ikan Asin Kelompok Mawar Putih di Desa Lhok Seudu Kecamatan Leupung Kabupaten Aceh Besar, Tahun 2017

\begin{tabular}{cccc}
\hline No. & Motif & $\begin{array}{c}\text { Jumlah } \\
\text { (Orang) }\end{array}$ & $\begin{array}{c}\text { Persentase } \\
(\mathbf{\%})\end{array}$ \\
\hline 1. & Motif Pencari Nafkah Utama & 3 & $17 \%$ \\
2. & Motif Menambah Pengahasilan & 10 & $55 \%$ \\
3. & Motif Mengisi Waktu Luang & 5 & $28 \%$ \\
\hline & Jumlah & $\mathbf{1 8}$ & $\mathbf{1 0 0}$ \\
\hline
\end{tabular}

Sumber: Data Primer (diolah), 2017

Berdasarkan tabel data diatas menunjukkan bahwa jumlah pedagang perempuan responden pada kelompok pengelolaan ikan asin Mawar Putih di desa Lhok Seudu Kecamatan Leupung Kabupaten Aceh Besar sebanyak 18 orang dengan motif bekerja untuk menambah pengahasilan merupakan motif utama dilakukan oleh pedagang perempuan responden dengan persentase mencapai 55\% yang dilakukan oleh 10 orang diikuti dengan 
motif bekerja untuk mengisi waktu luang $28 \%$ yang dilakukan oleh 5 orang dan motif bekerja sebagai pencari nafkah utama keluarga sebesar $17 \%$ yang dilakukan oleh 3 orang.

Di daerah penelitian, kategori perempuan yang masih memiliki suami berada pada motif menambah penghasilan dan motif mengisi waktu luang dengan responden berjumlah 15 orang, sedangkan kategori perempuan berstatus janda berada pada motif pencari nafkah utama dengan responden berjumlah 3 orang.

\section{Motif sebagai Pencari Nafkah Utama}

Berdasarkan tabel data menunjukkan bahwa motif bekerja sebagai pencari nafkah utama pada pedagang perempuan responden dalam kelompok pengelolaan ikan asin Mawar Putih di desa Lhok Seudu Kecamatan Leupung Kabupaten Aceh Besar adalah motif yang paling terendah pada kategori motif yaitu dengan persentase $17 \%$. Dari hasil penelitian, yang cenderung mengarah dalam kategori motif bekerja sebagai pencari nafkah utama adalah responden yang tidak memilki suami atau berstatus janda yang terdapat pada 3 responden perempuan pedagang ikan asin.

Pekerjaan yang dilakukan perempuan pedagang ikan asin yang tidak memiliki suami sangatlah berat dari pedagang perempuan yang masih memiliki suami. Peran ganda yang telah dilakukan oleh perempuan responden pedagang ikan asin membuat mereka bekerja lebih keras dan berani menghadapi segala resiko. Dari hasil penelitian, pedagang yang berstatus janda memiliki beban tanggungan yang berat dari segi pendapatan untuk menafkahi keluarganya.

\section{Motif untuk Menambah Penghasilan}

Kondisi ekonomi keluarga seringkali memaksa perempuan untuk ikut bekerja untuk menambah penghasilan keluarga. Seringkali kebutuhan rumah tangga yang begitu besar dan mendesak, membuat suami dan isteri harus bekerja untuk bisa mencukupi kebutuhan seharihari. Kondisi tersebut membuat sang istri tidak mempunyai pilihan lain kecuali ikut mencari pekeraan di luar rumah (Rozalinda, 2013).

Perempuan yang bekerja sebagai pedagang ikan asin di daerah Lhok Seudu dikarenakan tuntutan ekonomi pada keluarga mereka. Umumnya faktor yang membuat pedagang perempuan bekerja untuk menambah penghasilan keluarga yaitu untuk membiayai sekolah anak-anak mereka ke jenjang pendidikan yang lebih tinggi setelah anak-anak mereka menamatkan sekolah menengah atas (SMA).

\section{Motif untuk Mengisi Waktu Luang}

Wanita (istri) yang setiap harinya melakukan pekerjaan rumah tangga pada akhirnya akan merasa bosan jika semua waktunya dihabiskan untuk melakukan pekerjaan rumah tangga. Adanya waktu luang bagi wanita mendorong mereka memutuskan untuk bekerja sehingga menghindari rasa bosan/jenuh. Hoffman (2007) berpendapat bahwa salah satu yang mendasari wanita bekerja adalah adanya ketersediaan waktu luang memotivasi mereka untuk mencari alternatif kegiatan selain pekerjaan rumah untuk menghilangkan kejenuhan/kebosanan.

Berdasarkan data persentase motif menunjukkan bahwa persentase motif bekerja untuk mengisi waktu luang pada pedagang perempuan responden dalam kelompok pengelolaan ikan asin Mawar Putih di desa Lhok Seudu Kecamatan Leupung Kabupaten Aceh Besar adalah sebesar $28 \%$ dengan responden berjumlah 5 orang. Pada hasil penelitian, kategori motif bekerja untuk mengisi waktu luang dilakukan oleh perempuan pedagang responden yang masih memiliki suami. Beberapa dari mereka (pedagang ikan asin kelompok Mawar Putih) bekerja hanya untuk hobi juga mengisi waktu ketika anak-anak mereka bersekolah dan tidak setiap hari menjalankan aktivitasnya sebagai pedagang ikan asin, mereka bekerja jika pekerjaan rumah tidak menumpuk. 


\section{Analisis Pendapatan Usaha Dagang Ikan Asin \\ Biaya Produksi}

Biaya produksi adalah biaya yang dikeluarkan selama proses produksi berlangsung, baik biaya tetap, seperti Kios (sokes), meja jualan, kayu jemur, kursi, lampu, terpal dan pisau serta biaya tidak tetap (variabel), seperti ikan, garam, tali rafia serta bahan bakar.

\section{Biaya Penyusutan Alat pada Usaha Dagang Ikan Asin}

Biaya penyusutan alat termasuk ke dalam biaya tetap. Adapun peralatan yang digunakan dalam usaha dagangan ikan asin, meliputi kios, meja jualan, kayu jemur, kursi, lampu, terpal, ember dan pisau. Untuk lebih jelasnya dapat dilihat pada tabel data berikut ini.

Tabel 1. Rata-Rata Biaya Penyusutan Peralatan pada Usaha Dagang Ikan Asin Kelompok Mawar Putih di Desa Lhok Seudu Kecamatan Leupung Kabupaten Aceh Besar, Tahun 2017

\begin{tabular}{clcccc}
\hline No. & \multicolumn{1}{c}{ Uraian } & Satuan & $\begin{array}{c}\text { Harga } \\
(\text { Rp/Satuan })\end{array}$ & $\begin{array}{c}\text { Jumlah } \\
\text { (Unit) }\end{array}$ & $\begin{array}{c}\text { Total Biaya } \\
\text { (Rp/Bulan) }\end{array}$ \\
\hline 1. & Kios & Unit & 2.100 .000 & 1 & 11.444 \\
2. & Meja Jualan & Unit & 250.000 & 2 & 15.496 \\
3. & Kayu Jemur & Unit & 97.500 & 13 & 43.385 \\
4. & Kursi & Unit & 46.000 & 3 & 10.449 \\
5. & Lampu & Unit & 40.000 & 4 & 17.623 \\
6. & Terpal & Unit & 50.000 & 2 & 4.254 \\
7. & Kulkas & Unit & 2.000 .000 & 1 & 2.500 \\
8. & Ember & Unit & 8.000 & 4 & 3.516 \\
9. & Pisau & Unit & 10.000 & 4 & 4.417 \\
\hline \multicolumn{5}{r}{} & Total Biaya \\
\hline
\end{tabular}

Sumber: Data Primer (diolah), 2017

Berdasarkan tabel data diatas menunjukkan bahwa rata-rata biaya penyusutan per pedagang responden adalah sebesar Rp. 109.834/Bulan. Dapat dilihat pula bahwa rata-rata biaya penyusutan terbesar terdapat pada peralatan kayu jemur, yaitu sebesar Rp. 43.385/ Bulan dengan jumlah sebanyak 13 unit. Hal ini dikarenakan kayu jemur merupakan salah satu alat yang wajib ada untuk memudahkan pedagang ikan asin dalam pengolahan ikan sebelum menjadi ikan asin, juga kayu jemur sangat banyak mengeluarkan biaya pembuatan awal dengan rata-rata satuan harga sebesar Rp.97.500/unit. Pada biaya penyusutan peralatan, terdapat uraian yang hanya dihitung biaya perawatannya saja yaitu kulkas pendingin (freezer) ikan yang merupakan hibah dari pemerintah daerah kepada pedagang perempuan di kelompok pengelolaan ikan asin Mawar Putih.

\section{Biaya Sarana Produksi pada Usaha Dagang Ikan Asin}

Sarana produksi yang digunakan pada usaha dagang ikan asin dalam penelitian ini adalah ikan, garam, bahan bakar, dan tali rafia. Adapun biaya sarana produksi yang dibutuhkan pada usaha dagang ikan asin dapat dilihat pada tabel 2. 
Tabel 2. Rata-Rata Biaya Sarana Produksi pada Usaha Dagang Ikan Asin Kelompok Mawar Putih di Desa Lhok Seudu Kecamatan Leupung Kabupaten Aceh Besar, Tahun 2017

\begin{tabular}{clcccc}
\hline No & Sarana Produksi & Satuan & $\begin{array}{c}\text { Jumlah } \\
\text { (Unit) }\end{array}$ & $\begin{array}{c}\text { Harga Beli / } \\
\text { Upah (Rp/Unit) }\end{array}$ & $\begin{array}{c}\text { Total Biaya } \\
\text { (Rp/Bulan) }\end{array}$ \\
\hline 1. & Ikan & $\mathrm{Kg}$ & 30,4 & $46.675,7$ & 1.415 .278 \\
2. & Garam & $\mathrm{Kg}$ & 30 & 5.000 & 150.000 \\
3. & Bahan Bakar & $\mathrm{Liter}$ & 29,1 & 7.000 & 204.167 \\
4. & Tali Rafia & $\mathrm{Bal}$ & 3 & 7.000 & 21.000 \\
5. & Bubuk Kopi & $\mathrm{Kg}$ & 0,5 & 30.000 & 14.467 \\
\hline \multicolumn{2}{c}{ Jumlah } & & $\mathbf{9 3}$ & $\mathbf{9 5 . 6 7 6}$ & $\mathbf{1 . 8 0 4 . 8 3 9}$ \\
\hline
\end{tabular}

Sumber: Data Primer (diolah), 2017

Berdasarkan tabel data diatas menunjukkan bahwa rata-rata biaya sarana produksi adalah sebesar Rp. 1.804.839. Biaya sarana produksi terbesar terdapat pada penggunaan sarana produksi ikan sebesar Rp. 1.415.278/Bulan, dikarenakan ikan merupakan sarana produksi terpenting di dalam usaha dagang ikan asin dengan jumlah rataan unit per pedagang perempuan responden sebesar 30,4 dan harga beli per unitnya sebesar Rp. 46.675,7.

\section{Biaya Tenaga Kerja pada Usaha Dagang Ikan Asin}

Tenaga kerja yang digunakan pada usaha dagang ikan asini ini adalah tenaga kerja yang berasal dari dalam keluarga. Adapun biaya tenaga kerja yang dibutuhkan pada usaha dagang ikan asin dapat dilihat pada tabel data berikut ini.

Tabel 3. Rata-Rata Biaya Tenaga Kerja pada Usaha Dagang Ikan Asin Kelompok Mawar Putih di Desa Lhok Seudu Kecamatan Leupung Kabupaten Aceh Besar, Tahun 2017

\begin{tabular}{ccccc}
\hline No & Jenis Kegiatan & $\begin{array}{c}\text { Jumlah } \\
\text { (Orang) }\end{array}$ & $\begin{array}{c}\text { Upah } \\
\text { (Rp/Bulan) }\end{array}$ & $\begin{array}{c}\text { Total Biaya } \\
\text { (Rp/Bulan) }\end{array}$ \\
\hline 1. & Pengolahan Ikan & 1 & 91.400 & 103.190 \\
2. & Pengemasan Ikan & 1 & 77.000 & 78.571 \\
\hline & Jumlah & $\mathbf{1 8}$ & $\mathbf{3 . 0 2 5 . 2 0 0}$ & $\mathbf{3 . 2 7 1 . 3 6 3}$ \\
\hline & Rata-rata & $\mathbf{1}$ & $\mathbf{1 6 8 . 0 6 7}$ & $\mathbf{1 8 1 . 7 4 2}$ \\
\hline
\end{tabular}

Sumber: Data Primer (diolah), 2017

Berdasarkan tabel data diatas menunjukkan bahwa rata-rata tenaga kerja pada usaha dagang ikan asin Kelompok Mawar Putih di Desa Lhok Seudu berjumlah 1 orang dengan upahan rata-rata per bulan untuk pengolahan ikan sebesar Rp. 91.400 dan pengemasan ikan Rp. 77.000 dan rata-rata total biaya yang dikeluarkan oleh pedagang perempuan responden terhadap pada usaha dagang ikan asin sebesar Rp. 181.742. Tenaga kerja yang digunakan pada usaha dagang ikan asin ini adalah tenaga kerja yang berasal dari dalam keluarga. Pada umumnya kegiatan dilakukan sendiri oleh perempuan pedagang responden, dengan kegiatan yang meliputi pengolahan ikan (perendaman ikan, penggaraman ikan, penyiangan ikan, penjemuran ikan) pengemasan ikan hingga menjaga kios.

\section{Total Biaya Produksi pada Usaha Dagang Ikan Asin}

Biaya produksi merupakan biaya yang dihitung dari semua biaya yang dikeluarkan, meliputi biaya tetap, yaitu biaya penyusutan, serta biaya variabel, yaitu biaya sarana produksi, biaya tenaga kerja dan biaya lain-lain. Berikut ini adalah total biaya produksi usaha dagang ikan asin di kelompok pengelolaan ikan asin Mawar Putih desa Lhok Seudu dapat dilihat pada tabel data berikut ini. 
Tabel 4. Rata-Rata Total Biaya Produksi pada Usaha Dagang Ikan Asin Kelompok Mawar Putih di Desa Lhok Seudu Kecamatan Leupung Kabupaten Aceh Besar, Tahun 2017

\begin{tabular}{clc}
\hline No. & \multicolumn{1}{c}{ Uraian } & $\begin{array}{c}\text { Total Biaya } \\
(\text { Rp/Bulan })\end{array}$ \\
\hline 1. & $\begin{array}{l}\text { Biaya Tetap } \\
\text { Penyusutan Alat }\end{array}$ & 109.834 \\
\hline 2. & $\begin{array}{l}\text { Biaya Tidak Tetap (Variabel) } \\
\text { Sarana Produksi }\end{array}$ & 1.804 .839 \\
\hline 3. & Tenaga Kerja & 181.742 \\
\hline & $\quad$ Total Biaya & $\mathbf{2 . 0 9 6 . 4 1 5}$ \\
\hline
\end{tabular}

Sumber: Data Primer (diolah), 2017

Berdasarkan tabel data menunjukkan bahwa rata-rata total biaya yang harus dikeluarkan oleh pedagang perempuan responden setiap bulannya adalah sebesar Rp.2.096.415, dengan sarana produksi memerlukan biaya terbesar yaitu Rp.1.804.839, kemudian diikuti oleh upah terhadap tenaga kerja sebesar Rp. 181.742 dan penyusutan alat sebesar Rp. 109.834.

\section{Produksi, Harga Jual Produk dan Penerimaan}

Produksi yang dimaksudkan pada penelitian ini, yaitu barang (produk) dari proses produksi yang dihasilkan pada usaha dagang ikan asin dalam satuan kilogram, sedangkan nilai produksi merupakan penerimaan kotor yang diperoleh dari hasil rata-rata produksi ikan asin dikalikan dengan harga jual ikan asin yang dinyatakan dalam satuan rupiah. Pada harga jual produk yang dimaksudkan pada penelitian ini, yaitu yang berlaku pada saat penelitian ini dilakukan. Berikut ini adalah produksi, harga jual produk dan nilai produksi pada usaha dagang ikan asin dapat dilihat pada tabel data berikut ini.

Tabel 5. Rata-Rata Produksi, Harga Jual Produk dan Penerimaan pada Usaha Dagang Ikan Asin Kelompok Mawar Putih di Desa Lhok Seudu Kecamatan Leupung Kabupaten Aceh Besar, Tahun 2017

\begin{tabular}{llcc}
\hline No. & Uraian & Satuan & $\begin{array}{c}\text { Total Biaya } \\
(\mathbf{R p} / \text { Bulan })\end{array}$ \\
\hline & & \\
1. & Produksi & $\mathrm{Kg}$ & 49.125 \\
2. & Harga Jual Produk & $\mathrm{Rp} / \mathrm{Kg}$ & 101.250 \\
\hline \multicolumn{2}{c}{ Penerimaan } & $\mathbf{2 . 9 4 8 . 1 4 4}$ \\
\hline
\end{tabular}

Sumber: Data Primer (diolah), 2017

Berdasarkan tabel data menunjukkan bahwa rata-rata penerimaan yang diperoleh pedagang perempuan responden pada usaha dagang ikan asin di daerah penelitian, yaitu sebesar Rp. 2.948.144/Bulan, dengan produksi per bulannya mencapai Rp.49.125 dan harga jual produk sebesar Rp. 101.250/Kg. Hal ini dikarenakan harga jual produk yang berfluktuasi setiap harinya. Semakin tinggi harga jual produknya, maka semakin besar pula penerimaan yang diterima oleh pedagang perempuan responden.

\section{Pendapatan}

Untuk mengetahui besarnya keuntungan yang diperoleh pedagang perempuan responden pada usaha dagang ikan asin di kelompok mawar putih desa Lhok Seudu Kecamatan Leupung Kabupaten Aceh Besar dapat dilihat pada tabel 6. 
Tabel 6. Rata-Rata Pendapatan pada Usaha Dagang Ikan Asin Kelompok Mawar Putih di Desa Lhok Seudu Kecamatan Leupung Kabupaten Aceh Besar, Tahun 2017

No. Uraian

Total Biaya

(Rp/Bulan)

1. Total Penerimaan

2.948 .144

2. Total Biaya Produksi

2.096 .434

\section{Pendapatan}

851.710

Sumber: Data Primer (diolah), 2017

Dari hasil penelitian terhadap pedagang perempuan responden pada usaha dagang ikan asin kelompok mawar putih di Desa Lhok Seudu Kecamatan Leupung Kabupaten Aceh Besar, pendapatan yang diterima oleh masing-masing responden berbeda-beda dengan pendapatan pedagang perempuan responden terbesar dengan total pendapatan sebesar Rp. $\mathrm{Rp}$ 1.332.079, sedangkan pendapatan pedagang perempuan responden terkecil dengan total pendapatan sebesar Rp. 536.849. Pada hasil penelitian, kategori perempuan yang masih memiliki suami mempunyai rata-rata pendapatan sebesar Rp.852.725 dengan responden berjumlah 15 orang, sedangkan kategori perempuan berstatus janda mempunyai rata-rata pendapatan sebesar Rp.846.715 dengan responden berjumlah 3 orang. Dapat diketahui bahwa semakin besar jumlah penerimaan yang diterima oleh pedagang perempuan, maka semakin besar pendapatan yang diperoleh pedagang perempuan responden tersebut.

\section{Pendapatan Berdasarkan Motif Bekerja}

Untuk mengetahui besarnya rata-rata pendapatan berdasarkan motif yang diperoleh pedagang perempuan responden pada usaha dagang ikan asin di kelompok mawar putih desa Lhok Seudu Kecamatan Leupung Kabupaten Aceh Besar dapat dilihat pada tabel data berikut ini.

Tabel 7. Pendapatan rata-rata Berdasarkan Motif Bekerja pada Usaha Dagang Ikan Asin Kelompok Mawar Putih di Desa Lhok Seudu Kecamatan Leupung Kabupaten Aceh Besar, Tahun 2017

\begin{tabular}{|c|c|c|c|}
\hline No. & Uraian & $\begin{array}{c}\text { Jumlah } \\
\text { Responden }\end{array}$ & $\begin{array}{c}\text { Total Pendapatan } \\
\text { (Rp/Bulan) }\end{array}$ \\
\hline 1. & Motif Pencari Nafkah Utama & 3 & 846.807 \\
\hline 2. & $\begin{array}{l}\text { Motif Menambah } \\
\text { Pengahasilan }\end{array}$ & 10 & 868.199 \\
\hline 3. & Motif Mengisi Waktu Luang & 5 & 790.705 \\
\hline & Rata-rata & 18 & 851.718 \\
\hline
\end{tabular}

Sumber: Data Primer (diolah), 2017

Pada hasil penelitian, pendapatan rata-rata motif pada kategori ini merupakan yang terendah dari kategori pendapatan rata-rata berdasarkan motif bekerja, ini dikarenakan curahan kerja responden dalam kategori motif ini lebih sedikit dari responden dengan motif menambah penghasilan dan pencari nafkah utama yaitu selama 4-5 jam/hari. Curahan jam kerja mempengaruhi pendapatan dari pedagang perempuan responden. 


\section{Kontribusi Perempuan Terhadap Pendapatan Keluarga}

Tabel 8. Persentase Besaran Kontribusi Pendapatan Pedagang Perempuan pada Usaha Dagang Ikan Asin Kelompok Mawar Putih di Desa Lhok Seudu Kecamatan Leupung Kabupaten Aceh Besar, Tahun 2017

\begin{tabular}{clccc}
\hline No & \multicolumn{1}{c}{ Uraian } & $\begin{array}{c}\text { Jumlah } \\
(\text { Orang }\end{array}$ & $\begin{array}{c}\text { Persentas } \\
\mathbf{e} \\
(\mathbf{\%})\end{array}$ & $\begin{array}{c}\text { Besaran } \\
\text { Kontribusi } \\
(\boldsymbol{\%})\end{array}$ \\
\hline 1 & $\begin{array}{l}\text { Persentase Tinggi }>75 \% \\
\text { Persentase Sedang } 35 \%-\end{array}$ & 3 & $16,6 \%$ & $100 \%$ \\
2 & $\begin{array}{l}\text { 75\% } \\
3\end{array}$ & 12 & $66,6 \%$ & $39 \%$ \\
\hline Jumlah & Persentase Rendah $<35 \%$ & 3 & $16,6 \%$ & $34 \%$ \\
\hline $\begin{array}{c}\text { Rata- } \\
\text { rata }\end{array}$ & $\mathbf{1 8}$ & $\mathbf{1 0 0 \%}$ & \\
\hline
\end{tabular}

Sumber: Data Primer (diolah), 2017

Kontribusi pendapatan perempuan terhadap ekonomi rumah tangga merupakan sumbangan yang diberikan oleh perempuan terhadap pendapatan rumah tangga, dimana sumbangan ini tidak ditambahi dari pendapatan suami/anak mereka.

\section{SIMPULAN DAN SARAN}

Motif perempuan pedagang ikan asin bekerja di desa Lhok Seudu Kecamatan Leupung Kabupaten Aceh Besar pada umumnya untuk menambah penghasilan keluarga. Tingkat kontribusi yang diberikan pedagang perempuan responden terhadap peningkatan ekonomi rumah tangganya berkategori sedang dengan acuan jika pendapatan dari perempuan nelayan pedagang ikan asin $35 \%-75 \%$ dari total pendapatan rumah tangga. Adanya perbaikan sistem perdagangan pemasaran ikan asin untuk dapat mengekspor hasil dagangan (Ikan Asin) ke luar daerah hingga luar negeri agar semakin meningkatnya pendapatan yang diberikan oleh perempuan pedagang ikan asin terhadap peningkatan ekonomi rumah tangga nelayan. Untuk mendorong kemampuan berdagang dari perempuan pedagang ikan asin di desa Lhok Seudu Kecamatan Leupung Kabupaten Aceh Besar, maka pemerintah terutama Dinas Perindustrian dan Perdagangan Aceh dan Dinas Perikanan dapat memberikan penyuluhan bagaimana cara meningkatkan pendapatan dari perempuan pedagang ikan asin agar kontribusinya semakin meningkat terhadap peningkatan ekonomi rumah tangga nelayan.

\section{DAFTAR PUSTAKA}

Arikunto, S. 2006. Prosedur Penelitian Suatu Pendekatan Praktik. PT Rineka Cipta.Jakarta.

Bakosurtanal. 2006. Buku Tahunan. Pusat Survei Sumber Daya Alam Laut. Bogor.

Fachruddin, A. 2011. Kajian Tingkat Motivasi Nelayan Menangkap Ikan Kakap Merah Serta Kontribusinya Terhadap Total Pendapatan Keluarga Nelayan di Oesapa Kabupaten Kupang Provinsi Nusa Tenggara Timur. Fakultas Pertanian Jember. Jember.

Fajriadi., Hamzah, A., dan S, Nur, 2013. Analisis Probabilitas Kemiskinan Nelayan di Kota Banda Aceh. Jurnal Ilmu Ekonomi Pascasarjana Universitas Syiah Kuala. Vol. 1 No. 1.

Guritno, T.1992. Kamus Ekonomi. Erlangga, Jakarta. 
Hadeli. 2006. Metode Penelitian Kependidikan. PT. Ciputat Press, Jakarta.

Handoko, Hani T., Dr.MBA., dan Reksohadiprodjo S. 1996. Organisasi Perusahaan. Edisi kedua BPFE. Yogyakarta.

Handoko, W., Marwah, S., Ardhanariswari, R., 2012. Pembentukan model pemberdayaan perempuan nelayan di daerah tertinggal. Jurnal Masyarakat, Kebudayaan dan Politik Vol. 25 No.3 hal. 195-201.

Harahap, A., Fauzia, L., dan Emalisa. 2013. Peranan Istri Nelayan Terhadap Pendapatan Keluarga(Kasus:Desa Bagan Serdang, Kecamatan Pantai Labu,

Kabupaten Deli Serdang). Journal on social Economicof Agricuture and Agribusiness Vol. 2. No. 9.

Haryanto, S. 2011. Sosiologi Ekonomi. Ar-Ruzz Media. Yogyakarta.

Hasibuan, Malayu S. P, 2006, Manajemen Dasar, Pengertian, dan Masalah. Edisi Revisi, Bumi Aksara. Jakarta.

Hernanto, F. 1984. Aspek-aspek Pendapatan Ekonomi. Badan Penelitian dan Pengembangan Pertanian. Jakarta.

Hidayatullah, A. 2011. Kontribusi Usahatani Jagung Terhadap Pendapatan Petani di Desa Pulai D Amar Kecamatan Banjang Kabupaten Hulu Sungai Utara. Media Sains, Vol. 3(1): 67.

Ilham Zulfahmi, 2016. Nelayan Aceh. Opini dalam Harian Serambi Indonesia "Nelayan Aceh: Melarat Di Darat, "Meukarat" Di Laut", dikutip dari: http://aceh.tribunnews.com/2016/06/14/nelayan-aceh, diakses pada hari Kamis, 15 Desember 2016, pukul : 11.50 WIB.

Laila, N.E.N., dan Amanah, S, 2015. Jurnal Sosiologi Pedesaan. Hal 159-168.

Lestari, Endah., Imam Santoso., dan Rina Dwi Sulastri. 1997. Kontribusi Wanita Dalam Agribisnis Gula Semut Di Kabupaten Blitar Propinsi Jawa Timur. Jurnal Penelitian Ilmu-Ilmu Sosial (Social Science) Volume 9 Nomor : 47-53. Lembaga Penelitian Universitas Brawijaya. Malang.

Loekman Soetrisno. 1997. Kemiskinan, Perempuan, dan Pemberdayaan. Kanisius. Yogyakarta.

Lubis, L.A. 2009. Peranan Tenaga Kerja Wanita Pedagang Hortikultura Di Pasar Tradisional Terhadap Pendapatan Keluarga. Departemen Sosial Ekonomi

Pertanian. Fakultas Pertanian. Universitas Sumatera Utara. Medan.

Mangkunegara, A.P. 2005. Evaluasi Kinerja. Refika Aditama. Bandung.

Mubyarto.1987. Peluang Kerja dan Berusaha di Pedesaan. Fakultas Ekonomi Universitas Gajah Mada. Yogyakarta.

.1997. Pengantar Ekoper. LP3ES. Jakarta.

Mugni, A. 2006. Strategi Rumah Tangga Nelayan Dalam Mengatasi Kemiskinan. Fakultas Pertanian. Institut Pertanian Bogor. Bogor.

Mulyadi, 2005. Ekonomi Kelautan. PT. Rajagarfindo Persada. Jakarta.

Nazir, M. 1988. Metode Penelitian. Ghalia Indonesia. Jakarta.

Nazir. 2003. Metode Penelitian. Ghalia Indonesia. Jakarta.

Nurmanaf, A. R. 2006. Peranan sektor luar pertanian terhadap kesempatan dan pendapatan di pedesaan berbasis lahan kering. Jurnal SOCA vol 8. no3. November 2008, hal 318-322.

Oppong, c dan Chuch K. 1981. A Field to Research on Roles of Women. Focused Biographies. ILO. Geneva. 
Papanek, H. 1980. Development Planning for Women : The Implication of Women' Work, in Women and Development. Institute of Law and International Affaires. Bangladesh.

Primininingtyas, D.N. 2007. Analisis Sosial Ekonomi Peranan Perempuan Pedesaan di Dalam Keluarga dan Masyarakat. Buana Sains Vol 7 No 2: 193-202.

Priyono, T.F., \& Rahardjo. (2005). Eksploitasi Hubungan Pandega-Juragan dalam Modernisasi Perikanan Tangkap di Desa Grajagan, Kecamatan Purwoharjo, Kabupaten Banyuwangi. Sosiosains, 18 (2), 325-339. Banyuwangi.

Rahardjo, Susilo \& Gudnanto. (2011). Pemahaman Individu Teknik Non Tes. Nora Media Enterprise. Kudus.

Rozalinda. 2013. Peran Wakaf Dalam Pemberdayaan Ekonomi Perempuan. http://bwi.or.id/index.php/ar/publikasi/artikel/1123-peran-wakaf-dalam-

pemberdayaan\%20ekonomi-perempuan-1.html. Diakses pada tanggal 20 desember 2016. Pukul $17: 00$.

Sadili Samsudin. 2005. Manajemen Sumber Daya Manusia. Pustaka Setia. Bandung.

Sajogyo, Pudjiwati. 1985. Peranan Perempuan dalam Perkembangan Masyarakat Desa. Cv. Rajawali. Jakarta.

Sitorus M. 1998. Penelitian Kualitatif Suatu Perkenalan. Institut Pertanian Bogor. Fakultas Pertanian Bogor. Jurusan Iimu - ilmu dan Ekonomi Pertanian Laboratorium Sosiologi. Antropologi dan Kependudukan. Bogor.

Soekartiwi. 1993. Manajemen Pemasaran Dalam Bisnis Modern. Pustaka Harapan. Jakarta.

Sugiyono. 2001. Metode Penelitian Bisnis. Alfabeta. Bandung. 2008. Metode Penelitian Kuantitatif, Kualitatif dan R \& D. Alfabeta. Bandung. . 2010. Metode Penelitian Pendidikan: Pendekatan Kuantitatif, Kualitatif dan R \& D. Alfabeta. Bandung.

. 2012. Metode Penelitian Administrasi. Cetakan Ke-20. Penerbit Alfabeta. Bandung.

. 2014. Metode Penelitian Kuantitatif, Kualitatif, dan $R \& D$. Alfabeta. Bandung.

Sujawarti, A. 2013. Peran Perempuan Dalam Perekonomian Rumah Tangga Di Dusun Pantog Kulon, Banjaroya, Kalibawang, Kulon Progo. Program Studi Sosiologi. Fakultas Ilmu Sosial Dan Humaniora. Universitas Islam Negeri Sunan Kalijaga. Yogyakarta.

Sukesi, K. Dan Sugiyanto. 2002. Paradigma Baru Pemberdayaan Perempuan Di Era Globalisasi. Pusat Penelitian Peran Wanita. Lembaga Penelitian. Universitas Brawija. Malang.

Sukirno, S. 2002. Teori Mikro ekonomi. Cetakan Keempat. Rajawali Press. Jakarta.

Sukiyono, Ketut dan Sriyoto. 1997. Transformasi Struktural Wanita Transmigran Dan Kontribusinya Terhadap Pendapatan Rumah Tangga : Kasus Di Daerah Transmigrasi Sekitar Kotamadya Bengkulu. Jurnal Agro Ekonomi Volume 16 No. 1 dan 2 Oktober 1997. Fakultas Pertanian Universitas Bengkulu. Bengkulu.

Suratiah dkk, 1999. Dilema wanita antara industri rumah tangga dan aktifitas domestik. Aditya media. Yogyakarta. 
Widodo, Y. 2003. Analisis Faktor - Faktor yang mempengaruhi Ibu Rumah Tangga bekerja di Sektor Non Pertanian Dalam Meningkatkan Pendapatan Keluarga Publikasi Ilmiah Tesis. Program Pasca Sarjana Universitas Brawija. Malang.

Yandianto. 2000. Kamus Umum Bahasa Indonesia. M2S. Bandung.

Zen, L. A. 2009. Analisis Kontribusi Pendapatan Wanita Nelayan Di Kelurahan Pasie Nan Tigo Kecamatan Koto Tangah Kota Padang. Jurnal Mangrove dan Pesisir IX (1), Februari 2009: 12-17. ISSN: 1411-0679. Padang.

Zulfahmi,I.2016. Nelayan Aceh. (http://aceh.tribunnews.com/2016/06/14/nelayan-aceh)

Diakses pada tanggal 14 Desember 2016 